Федорієнко В. А.;

Головченко О. В.;

Васюхно C. I.

Центр воєнно-стратегічних досліджень Національного університету оборони України імені Івана Черняховського, Київ

\title{
Особливості сучасної концептуальної архітектури ГІС платформи військового призначення
}

Резюме. Стаття розкриває особливості ГІС архітектури та їі роль для Збройних Сил України. Проведений аналіз передумов переходу на єдину платформу ГІС та аналіз підходів НАТО щодо впровадження сучасних архітектур типу C4ISR. Визначена необхідність використання архітектури підприємства при впровадженні ГІС платформи. Наведені концептуальні особливості стратегії впровадження ГІС платформи та дані деякі рекомендації.

Ключові слова: рамкова архітектура, архітектура підприємства, ГIC платформа, C4ISR.

Постановка проблеми. Для втілення стандартів НАТО із дотриманням інтересів Міністерства оборони (МО) України та пріоритетів розвитку 3С України, було прийняте рішення щодо створення інформаційної інфраструктури МО України. Водночас, згідно другого розділу Стратегічного оборонного бюлетеня [1], одним із завдань $\epsilon$ створення автоматизованої системи C4ISR (Command, Control, Communications, Computers, Intelligence, Surveillance and Reconnaissance) складових сил оборони, яка відповідає стандартам, доктринам i рекомендаціям НАТО на всіх рівнях управління (тактичному, оперативному та стратегічному) із визначеною специфікою базових можливостей.

У НАТО використовують архітектурні підходи до впровадження інформаційних систем. Поняття "C4ISR" визначається як архітектура та концееція взаємодіi складових системи бойового управління оперативного та оперативно-стратегічного рівня. Спроможності закладені в архітектуру та концепцію C4ISR дають змогу: автоматично визначати положення i переміщення своїх підрозділів та військ противника (автоматично відображається на електронних картах); обирати маршрути руху; давати цілевказівки засобам вогневого ураження; інформувати свої підрозділи про дії i місцезнаходження їх сусідів і противника.

Із зазначеного випливає значимість ролі геоінформаційної системи (далі - ГІС) в складній інформаційній системі. Вона є однією з головних. Реалізація в НАТО (згідно методологій та стандартів) полягає у використанні ядра ГІС реалізованому на платформі ГІС. Тому, враховуючи передовий досвід, вимоги та стандарти НАТО, реалізація переходу 3C України до C4ISR без платформи ГІС не можлива.

3 точки зору розвитку інформаційної інфраструктури [2, 3], ЗС України потребують єдиної (головної) ГІС платформи. Для цього необхідно визначитися із загальним обрисом ГІС платформи, тобто, з іiі архітектурою. Тому, проведення аналізу архітектури ГІС платформи, що об'єднує основні принципи, концепції, правила, шаблони, інтерфейси, стандарти, кращі практики побудови платформи ГІС в IT інфраструктурі НАТО та визначення особливостей концептуальної архітектури ГІС платформи військового призначення для висвітлення шляхів адаптації у МО України є актуальною задачею.

Ступінь розробленості проблеми. Висвітленню концептуальних задач щодо розгортання рішень ГІС присвячена робота [4]. Аспекти застосування рамкових архітектур, при побудові ГІС архітектури рівня підприємства зазначені в джерелах $[5,6]$. В роботах $[7,8]$ висвітлені підходи щодо інтегрованих моделей ГІС військового призначення. Загальні принципи рамкових архітектур, прийнятих у НАТО, представлені в $[7,8]$. У роботі [3] розкрите поняття архітектури підприємства на основі аналізу сучасних світових підходів до проектування рамкових архітектур та визначене місце інформаційної інфраструктури МО України.

Метою статті є визначення особливостей концептуальної архітектури ГІС платформи військового призначення на основі аналізу 
провідних підходів до проектування ГІС у HATO.

Виклад основного матеріалу. Згідно 3 [4]: ГІС - це система, яка: по-перше, являє собою комплекс взаємодіючих п'яти компонентів, що складаються 3 комп'ютерних засобів, програмного забезпечення (ПЗ), географічних даних, регламенту та користувачів; по-друге, виконує функції введення, інтегрування, зберігання, обробки, аналізу, моделювання та візуалізації географічної інформації.

Перспективний сценарій. Для розуміння важливості створення повнофункціональної платформи ГІС наведемо перспективний сценарій у відповідності до підходів НАТО.

Припускаємо, що Збройні Сили (3С) України мають інформаційні системи командування, контролю та розвідки (С2I) в географічно рознесених місцях, де потрібні однакові дані для дій (операції). Група G3 (планування та оперативна група - у позначеннях НАТО) в Генеральному штабі ЗС України, розташованому в м. Києві, вимагає даних для ведення карти для планування операції. Оперативне командування S3 (згідно позначень НАТО), начальник управління оперативного відділу, працює в Одесі та потребує таких же даних, щоб уточнити план щодо розподілу сил i засобів, а також ролі командування в операції. Одночасно, командир бригади, що знаходиться в зоні АТО, залежить від інформації для виконання своїх задач. Тож, G3, S3 і командир бригади вимагають однакових баз даних, але для їх доставки можуть знадобитися різні комунікаційні та апаратні рішення. Оскільки виконання задач для операції $\epsilon$ найголовнішим пріоритетом, а суттєвим фактором $\epsilon$ час, i пересування по більшості шляхів $є$ ускладненим, тому рішення щодо доступності баз геоданних повинно бути легко підтриманим, а геопросторові дані - легко доступні та легко оновлені.

Таким чином, військовослужбовці, які працюють у різноманітних середовищах, часто в небезпечних умовах, потребують швидкого та легкого доступу до точної та найсучаснішої географічної інформації для (відповідно до інформаційних ресурсів НАТО): планування бою (операціi), оцінки місцевості, навігації, розвідувального аналізу (analyzing intelligence), управління логістикою тощо.

Отже, для забезпечення ефективності на всіх рівнях функціоналом ГІС необхідне створення ГІС платформи до якої будуть підключені користувачі.

ГІС платформа - це платформа ГІС, що об'єднує карти, додатки, дані та визначене коло користувачів 3 метою допомоги та підтримки окремих користувачів, органів управління та штабів всіх рівнів щодо підвищення рівня поінформованості та швидкості прийняття обгрунтованих рішень в рамках наданого авторизованого доступ до ГІС 3 використанням політики безпеки. Зауважимо, що ступінь інформативності та швидкості прямо пропорційно залежить від ступеню поширення ГІС у військовій галузі.

Разом 3 тим, знаходити, використовувати, створювати географічну інформацію та здійснювати обмін картами чи здійснювати їх поширення (публікацію електронної версії в мережі), за допомогою будь-якого пристрою (це може бути: стаціонарний комп'ютер, ноутбук, термінальна станція 3 веб-браузером, мобільні пристрої тощо) не залежно від місця та часу, $є$ досить стандартними процедурами за умови використання сучасної архітектури платформи ГІС. Архітектура платформи ГІС - це методологія планування, розробки та структури управління при впровадження платформи ГІС

Передумови переходу НАТО на нову ГІС платформу. На початку, НАТО потребувала сучасної інфраструктури інформаційних технологій (IT) на основі стандартів IT для обробки та роботи з геопросторовою інформацією, тобто створення ГІС наступного покоління. Велика кількість роз'єднаних та слабко об'єднаних застарілих систем для збору, керування, аналізу та розповсюдження геопросторової інформації не задовольняло потребам Альянсу, закладених виробниками спроможностей більшості систем. Існуючі системи не були спроможними обробити повний обсяг вхідних даних так, як були заснованими на застарілих технологіях. Вони часто були несумісні між собою. Визнаючи ГІС як фундаментальну технологію, було запропоноване нове геопросторове рішення, що б забезпечувало:

поширення комерційного програмного i технічного забезпечення на замовлення військового відомства (commercial off-the-shelf, COTS);

децентралізоване

управління геопросторовими даними в кожному штабі НАТО 3 централізованим контролем якості об'єднаних оперативних командувань НАТО;

стандартизовані завдання 3 розробки та розповсюдження ГІС;

покращений інтерфейс 3 функціями для служб НАТО (FAS) для управління логістичною та оперативною інформацією в рамках спільної оперативної картини (common operational picture, COP).

Корпоративна (підприємства) apхітектура. У попередніх публікаціях [2, 3] 
зверталася увага щодо використання рамкових архітектур або методологій при впровадженні концепцій єдиного управління типу C4ISR та інших спадкових архітектур (DoDAF, NAF та інші). В основу C4ISR покладені промислові методологічні рішення, такі, як архітектура підприємства (Enterprise Architecture, EA) та ряд відкритих архітектур [3, 10]. $E A$ інструмент, що включає методологію, який охоплює планування, розробку та структуру управління (архітектуру) на рівні підприємства. EA також складається 3 типових для рамкових архітектур операційних, системних та технічних поглядів чи бачень (operation view OV, system view SV, technical view TV). Як наслідок, створення архітектури, сумісної 3 класичною C4ISR, є головною умовою та тенденцією в діяльності НАТО.
Разом бачення архітектури надають загальній програмі структуру, яка допомагає динамічно керувати та управляти портфелем рішень, що включає інсталяцію геопросторової інформації та сервісів (installation geospatial information and services).

Під час застосування будь-якої методології рамкової архітектури досить часто піддають впливу (змінам) існуючу систему 3 метою приведення іiі у відповідність до прийнятих цілей (у поняттях бачень) 3 врахуванням результатів технічного прогнозування та вимог стандартів [11]. Приклад матриці бачень ЕА наведений в Табл. 1

Приклад технічного фрагменту матриці бачень для ГІС платформи за методологією корпоративної рамкової архітектури ЕА

\begin{tabular}{|c|c|c|c|c|c|c|}
\hline & Вимоги (Чому) & Дані (Які) & Процес (Як) & Мережа (Де) & Роль (Хто) & Час (Коли) \\
\hline $\begin{array}{l}\text { Операційні } \\
\text { бачення } \\
(\text { ЯК-С) }\end{array}$ & $\begin{array}{l}\text { Ідентифікація } \\
\text { функціональних } \\
\text { (бізнес) цілей / } \\
\text { стратегій. Як це } \\
\text { впливає на } \\
\text { відповідність в } \\
\text { Операційному } \\
\text { баченні (ЯК-Є) }\end{array}$ & $\begin{array}{l}\text { Які дані чи } \\
\text { сервіси } \\
\text { впливають на } \\
\text { Операційні } \\
\text { бачення (OV-1, } \\
\text { OV-2) }\end{array}$ & $\begin{array}{l}\text { Які процеси або } \\
\text { робочі потоки } \\
\text { змінилися за } \\
\text { рахунок } \\
\text { застосування } \\
\text { Операційних } \\
\text { бачень (OV-2, } \\
\text { OV-6) }\end{array}$ & $\begin{array}{l}\text { Визначення } \\
\text { логістичних } \\
\text { напрямків в } \\
\text { Операційних } \\
\text { баченнях, що } \\
\text { будуть залежати } \\
\text { від обраного } \\
\text { місця чи впливу } \\
(\mathrm{OV}-1, \mathrm{OV}-2)\end{array}$ & $\begin{array}{l}\text { Які операційні } \\
\text { ролі необхідно } \\
\text { посилити? Де } \\
\text { здійснити це } \\
\text { посилення? } \\
\text { (OV-2) }\end{array}$ & $\begin{array}{l}\text { Скільки є часу } \\
\text { для } \\
\text { доопрацюванн } \\
\text { я / очікування } \\
\text { реалізації } \\
\text { етапів } \\
\text { проекту? }\end{array}$ \\
\hline $\begin{array}{l}\text { Системні } \\
\text { бачення } \\
(\text { ЯК-С) }\end{array}$ & $\begin{array}{l}\text { Які вимоги до } \\
\text { компонентів } \\
\text { технічних систем, } \\
\text { що пропонуються } \\
\text { до заміни? Які } \\
\text { системні вимоги } \\
\text { для програмного і } \\
\text { технічного } \\
\text { забезпечення? (SV- } \\
\text { 1) }\end{array}$ & $\begin{array}{l}\text { Які специфічні } \\
\text { бази даних, } \\
\text { архітектури } \\
\text { даних, форматів } \\
\text { і обміну даних } \\
\text { будуть впливати } \\
\text { на } \\
\text { запропоновані } \\
\text { зміни? (OV-7, } \\
\text { SV-2, SV-4) }\end{array}$ & $\begin{array}{l}\text { Які системно } \\
\text { пов'язані } \\
\text { компоненти або } \\
\text { робочі потоки } \\
\text { будуть піддані } \\
\text { впливу? (SV-1, } \\
\text { SV-4, SV-6) }\end{array}$ & $\begin{array}{l}\text { Де в ГІС- } \\
\text { архітектурі, } \\
\text { мережі тощо } \\
\text { буде цей вплив? } \\
\text { (SV-1, SV-4, } \\
\text { SV-6) }\end{array}$ & $\begin{array}{l}\text { Хто в цій } \\
\text { системі чи в } \\
\text { яких } \\
\text { операційних } \\
\text { вузлах буде } \\
\text { здійснювати } \\
\text { вплив? Які ролі } \\
\text { потрібно буде } \\
\text { додати або } \\
\text { 3мінити? (SV-1, } \\
\text { SV-4, SV-6) }\end{array}$ & $\begin{array}{l}\text { Які } \\
\text { орієнтовні } \\
\text { технічні етапи } \\
\text { / терміни } \\
\text { запропонован } \\
\text { их змін? }\end{array}$ \\
\hline $\begin{array}{l}\text { Технічні } \\
\text { бачення } \\
\text { (ЯК- } \\
\text { БУДЕ) }\end{array}$ & $\begin{array}{l}\text { Чи вимоги } \\
\text { узгоджується або } \\
\text { включають зміни в } \\
\text { рамках реалізації } \\
\text { технічних } \\
\text { прогнозів і цілей } \\
\text { Операційних } \\
\text { бачень ЯК-БУдЕ? } \\
\text { (Огляд бачень ЯК- } \\
\text { БУДЕ для ОV-1 і } \\
\text { ТV-2 технічних } \\
\text { прогнозів) }\end{array}$ & $\begin{array}{l}\text { Чи впливає } \\
\text { запропоноване } \\
\text { рішення або } \\
\text { узгоджується } 3 \\
\text { будь-якими } \\
\text { цілями чи } \\
\text { прогнозами } \\
\text { пов'язаними з } \\
\text { даними? }\end{array}$ & $\begin{array}{l}\text { Чи є будь-які } \\
\text { впливи на або } \\
\text { “вирівнювання" } \\
\text { з операційними } \\
\text { або системними } \\
\text { процесами? } \\
\text { (Огляд бачень } \\
\text { ЯК-БУДЕ для } \\
\text { OV-1, SV-1, SV- } \\
\text { 4) }\end{array}$ & $\begin{array}{l}\text { Чи буде } \\
\text { запропонована } \\
\text { зміна впливу } \\
\text { або } \\
\text { узгодженість } 3 \\
\text { цілями } \\
\text { системних } \\
\text { компонентів } \\
\text { архітектури, } \\
\text { обміну даних чи } \\
\text { мережі? }\end{array}$ & $\begin{array}{l}\text { Як зміни } \\
\text { впливають на } \\
\text { операційні або } \\
\text { системні цілі } \\
\text { користувачів і } \\
\text { операційних } \\
\text { вузлів? (Огляд } \\
\text { бачень ЯК- } \\
\text { БУДЕ для OV- } \\
\text { 2, SV-2) }\end{array}$ & $\begin{array}{l}\text { Коли і який } \\
\text { термін } \\
\text { необхідний } \\
\text { для реалізації } \\
\text { майбутніх } \\
\text { цілей або } \\
\text { завдань } \\
\text { відповідно до } \\
\text { методології } \\
\text { Архітектури } \\
\text { підприємства } \\
\text { (ЕА)? }\end{array}$ \\
\hline
\end{tabular}

ГIC ядро НАTO на ПЗ ArcGIS. Дослідження підтверджують [4], що протягом багатьох років світовим лідером в розробці і поширенні програмного забезпечення ГІС $\epsilon$ Інститут дослідження систем довкілля (Environmental Systems Research Institute ESRI). Компанією Esri створена потужна система програмних продуктів під назвою ArcGIS. Меншого поширення програмних продуктів ГІС мають інші виробники ГІС (3 відповідним ПЗ ГІС): Intergraph Corp. MGE
(Modular GIS Environment), GeoMedia GE Network Solution (General Electric Company), Smallworld GIS, Bentley Systems Inc. (MicroStation), Mapping Information Systems Corp. (MapInfo Professional), Autodesk Inc. (AutoCAD), Autodesk Map, Autodesk Survey.

Досить логічно, що у якості програмної складової ядра ГІС для НАТО є ПЗ ArcGIS (Esri). 32006 року НАТО співпрацює 3 компаніями Esri та Siemens Enterprise Communications 3 метою впровадження 
системи базової географічних сервісів НАТО (Core GIS HATO), інфраструктури геопросторових даних та послуг на рівні підприємства.

ПЗ ArcGIS, як основа для географічного рішення в НАТО базується на наступних продуктах:

- ArcGIS Desktop 3 розширеннями для високопродуктивних картографічних робочих станцій;

- ArcGIS Server 3 розширеннями просторового, тривимірного та зображення 3 геоприв' язкою;

- ArcGIS Workflow Manager для керування всіма завданнями ГІС, такими як оновлення карт та запитів для спеціальних геопросторових аналітичних продуктів;

- ArcGIS Engine та ArcGIS Web Mapping API для набору інструментів для розробників;

- Core Geo Viewer, індивідуальний 2D веб-переглядач GIS;

- ArcGIS Explorer, передовий переглядач 2D i 3D-GIS.

Ядро ГIC (Core GIS) HATO є частиною інформаційної інфраструктури [6] i надає централізовані геопросторові сервіси штабам НАТО та системам управління та контролю (C2). Відповідні сервіси та набори інструментів розгортаються на кожній з локальних мереж у 18 штаб-квартирах НАТО в 12 країнах. Це означає, що всі співробітники НАТО мають доступ до однієї стратегічної геопросторової інформації та геопродуктів, отже "воюють на єдиній карті".

Сервери НАТО 3 ГІС відповідають вимогам доступності за допомогою ряду стандартів), які $\epsilon$ основою для сприяння сумісності між системами НАТО та державамичленами. Серед них стандарти Міжнародної організації стандартизації (International Organization for Standardization, ISO) та відкритих веб-сервісів (Open Geospatial Consortium, OGC). Основна ГІС НАТО забезпечує відкриту структуру за допомогою саме веб-сервісів OGC, таких як служби веб-карт (Web Map Service, WMS), служби веб-покриття (Web Cover Service, WCS) та служби веб-властивостей (Web Feature Services, WFS).

Ядро ГIC HATO (NATO Core GIS ) використовує сучасну апаратну та програмну інфраструктуру для підтримки технології ГІС, у тому числі це багатотерабайтне та централізоване сховище середовища для знімків та інших геопросторових продуктів. Система управління базою даних Oracle $11 \mathrm{~g}$ технологічно відповідає за зберігання геопросторової інформації, такої як векторні геодані. Всі сервери платформи ГІС в
НАТО є масштабованими і здатні підтримувати велику та розподілену користувацьку спільноту.

У даний час співробітники НАТО у будьякому місці в світі можуть отримати доступ до геопросторових даних НАТО, додавати накладені на них місії у вигляді шарів геоданних та використовувати потужні інструменти для обробки географічних даних.

Концептуальні особливості. Стратегія впровадження програми. Забезпечення надійної географічної платформи для робочих процесів в організації повинна допомогти скоротити час щодо прийняття рішень. Обладнані додатками відповідні пристрої, дають змогу користувачам працювати ефективніше, використовуючи можливості ГІС. Потенційно, сучасна платформа ГІС здатна задовольнити специфічні галузеві функціональні потреби. Це досягається використанням спектру рішень щодо стратегії впровадження проекту ГІС. Кожне $з$ них пов'язане 3 витратами та зусиллями на його впровадження (рис.1). Нижче наведені послідовні ієрархічні рекомендації щодо зменшення подібних наслідків.

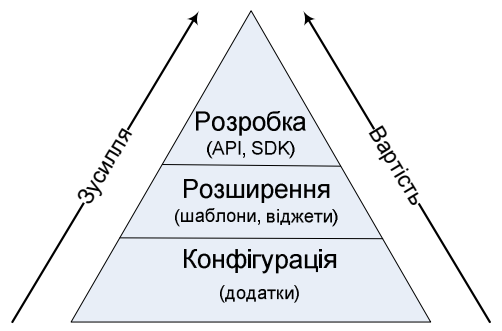

\section{Рис. 1. Стратегія впровадження проекту ГІС}

Периа рекомендаиія полягає в тому, що при впровадженні у певній організації чи установі слід підібрати найкращу конфігураиію шляхом максимального використання функцій існуючих програмних додатків, що були попередньо розроблені виробником ПЗ. Прикладом може бути придбання, так званих "комерційно-упакованих" продуктів рішень $[6,12]$ (COTS), що належать до права на користування ПЗ, які потім адаптуються для задоволення потреб організації за рахунок подальших налаштувань. Подібне впровадження має нижчу вартість, ніж введення в експлуатацію індивідуально виготовлених або замовлених заздалегідь рішень вузького функціонального спрямування. Підхід до налаштування COTS забезпечує значну частину можливостей iз найменшими зусиллями та найнижчою поточною вартістю.

3 аналізу опублікованих матеріалів кращих практик $[12,13]$, спочатку слід налаштувати, та використати настоювані додаткові програми, поза зоною функціональності ГІС, які розроблені таким чином, щоб задовольнити більшість потреб проекту 3 мінімальними зусиллями. Організації повинні прийняти філософію "першого 
налаштування", щоб уникнути зайвих витрат, пов'язаних 3 розробкою, технічним обслуговуванням та спеціалізованим навчанням.

Друга рекомендація. Якщо існує збільшена функціональна вимога, яка не може бути задоволена заданою виробником ПЗ конфігурацією, організаціям слід застосувати розширення існуючих програм за допомогою шаблонів та модульних налаштувань програмних інтерфейсів (віджетів). Також, слід застосовувати розширення наявних шаблонів та додатків, застосовуючи дискретні удосконалення шаблонів або інкапсулюючи нові функції в модулях або віджетах, які відповідають існуючим додаткам i apхітектурі. Наприклад, декілька додатків ArcGIS, такі, як ArcGIS Web App Builder та Dashboard Operations, забезпечують модульні шаблони або елементи керування віджетів, які розробники можуть використовувати для економії часу та зусиль. За допомогою цих додатків розробникам слід створювати нові віджети, щоб відповідати унікальним функціональним вимогам (бізнес-потребам), а потім підключати їх до існуючих додатків.

Третя рекомендаичія. Розробка для надання функцій, які неможливо досягти за допомогою будь-якого іншого із зазначених підходів. Перш, ніж прийняти рішення, щодо виходу за межі простого підходу налаштування конфігурації COTS, слід розглянути загальні витрати та зусилля, пов'язані як 3 розширенням, так i 3 налаштовуванням ПЗ. Це ресурси, початкові зусилля розробки, поточного адміністрування додатків, навчання користувачів та розробників, технічної підтримки тощо. Наприклад, використання розробки типу ArcGIS Web API та SDK $\epsilon$ складним i найважливішим під час створення ГІС платформи. Розробники повинні намагатися більш повно використовувати доступні компоненти такі, як ідентифікаційний менеджер, веб-карти, геоінформаційні інструменти та вебсценаріï (Identity Manager, Web Maps, Geoprocessing tools, and Web Scenes) для мінімізації зусиль 3 розробки та постійного технічного обслуговування.

Під час визначення найкращого підходу до забезпечення високої ефективності проекту, слід врахувати вплив обсягу вартості та зусиль кожного спектру рішень на стратегію впровадження проекту ГІС з метою скорочення часу проекту на використання нестандартних, налаштованих, розширюваних додатків i шаблонів. Вважають, що філософія "першої конфігурації" допомагає зменшити загальні витрати і дозволяє розробникам зосередитись на більш складних завданнях.

Концептуальна архітектура платформи ГІС. Виходячи з вимог щодо архітектури ГІС рівня підприємства (ЕА), платформа ГІС має складатися 3 трьох різних середовищ обчислень (рис. 2): продуктивної експлуатащіï, стейджингу (підготовки й отримання даних або перевірки якості і тестування) та розробки. Разом вони становлять, так зване, ізольоване середовище. Існує чотири основних сегменти кожного середовища: Додатки, Портал, Інфраструктура, Зовнішні системи та сервіси [6]. На рис. 2 зазначені ці сегменти.

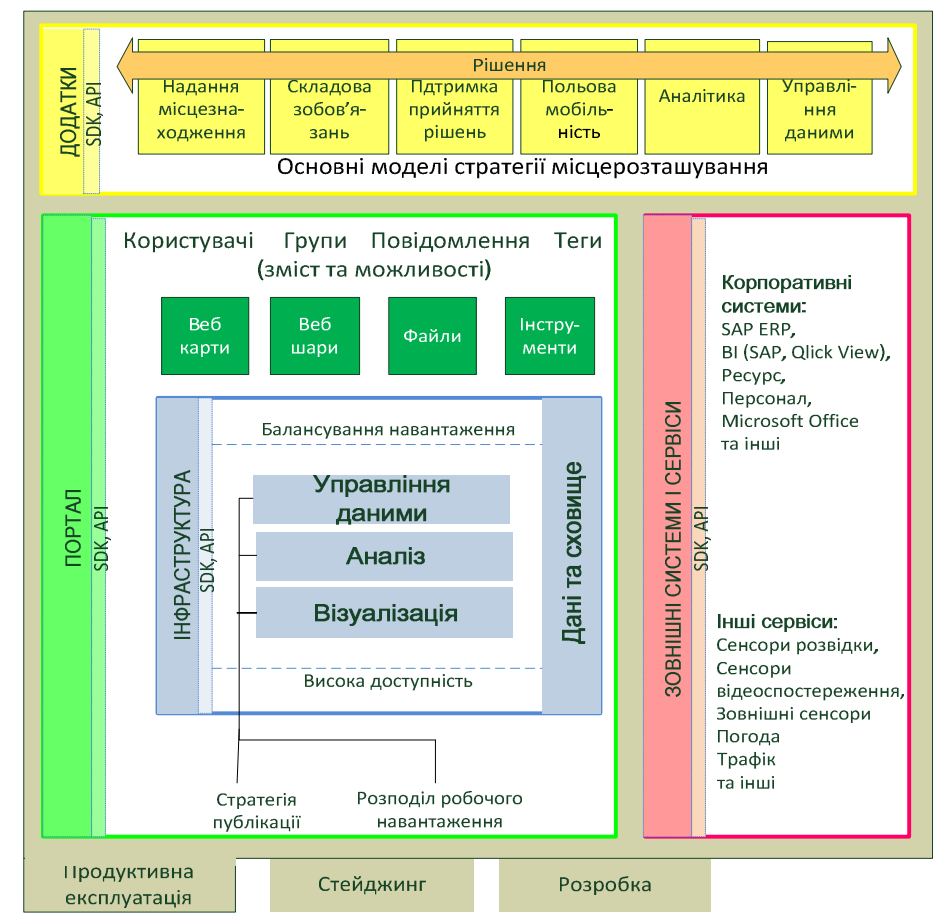

Рис. 2. Компоненти концептуальної архітектури ГІС платформи 
Секція Додатки включає компоненти платформи для інтерактивної взаємодії більшості користувачів включаючи програмні додатки для кінцевого користувача (наприклад, ArcGIS Pro, Collector for ArcGIS, Story Maps, and Operations Dashboard for ArcGIS).

Додатки, як правило, використовуються в робочих процесах, які відповідають одній або декільком із шести основних моделей стратегії місие розташування. Це - надання місцезнаходження, складової ліцензійних зобов'язань, підтримки прийняття рішень, польової мобільності, аналітики та управління даними).

Наприклад, модель можливості надання місиезнаходження розширює геопросторові спроможності для кожного структурного підрозділу за цільовим призначенням (через вебсайт і прості додатки) для аналітиків, керівників і польових користувачів - для виявлення, використання, створення та обміну картами. Наприклад, спостерігач, який фіксує дані про наслідки обстрілів у польових умовах може за допомогою Collector for ArcGIS виконати задачі покладені на модель польової мобільності на місиях. Особа, яка приймає рішення використовуючи ситуаційний екран (або оперативну інформаційну панель у вигляді дашборду) 3 метою спостереження за інформацією введеною співробітниками (наприклад, спостерігачами) на місцях у режимі реального часу, виконує модель підтримки прийняття рімення. Отже, програмні додатки з'єднують користувачів та їх функціональні процеси (бізнес-процеси) з платформою.

Секція Портал, як компонент платформи призначений для організації користувачів i з'єднання їх 3 відповідними вмістом i можливостями на основі їх ролей та повноважень у межах платформи. Портал використовує ідентифікацію особи для доставки потрібного вмісту потрібному користувачу у потрібний час. 3 точки зору виду програмного продукту, портал може бути реалізованим у вигляді локального рішення (наприклад, Portal for ArcGIS) або хмарного рімення (наприклад, ArcGIS Online). Портал забезпечує контроль доступу, правила керування вмістом та модель спільного доступу, яка дозволяе користувачам ділитися інформаційними продуктами по всій організації.

Компонент Інфраструктура включає технічну складову, програмне забезпечення, сервіси та сховища (репозитаріі) даних, які складають ядро платформи ГІС. Вважається, що найбільш важливими функціональними завданнями по даному компоненту, що пов'язані 3 інфраструктурою платформи є балансування навантаження, забезпечення високої доступності даних, розподіл робочого навантаження на систему, розробка стратегії публікації карт в режимі реального часу (он-лайн публікація).

Зовнішні системи та сервіси, як компоненти, включають інші системи, що надають сервіси ГІС або використовують ці сервіси для геопросторового забезпечення своїх можливостей. Здатність щодо вільного залучення геоданих 3 інших інформаційних систем $є$ ключовою умовою повноцінного функціонування сучасної ГІС платформи.

Щодо забезпечення базових умов, то для дотримання відповідності вимогам платформи ГІС щодо продуктивності, безпеки та доступності необхідне виконання наступних основних завдань щодо автоматизації,інтеграції на рівні галузі (MO України), ізоляції середовища, високої доступності, працездатності та достатності інфраструктури, балансування робочого навантаження, розробки та дотримання політики опублікування карт, забезпечення режиму реального часу, забезпечення безпеки (політики безпеки), розподілу робочого навантаження (використання трудомістких фонових завдань у не робочий час).

Забезпечення стратегії впровадження додатків, основної моделі стратегії місцерозташування, керування ідентифікацією, визначення пріоритетності проектів прямо пропорційно залежать від дій вищого керівництва та кваліфікаційного рівня спеціалістів в штаті організації. Увага зосереджуються на персоналі (адміністраторах, картографах, програмістах, користувачах) та його внутрішній взаємодіi.

Висновки. У роботі були визначені особливостей концептуальної архітектури ГІС платформи військового призначення на основі аналізу провідних підходів до проектування ГIC у НАТО за рахунок уточнення понять, змісту та особливості архітектури ГІС. Визначене місцеГІС в рамковій архітектурі побудови інформаційних систем НАТО.

Подальші дослідження слід присвятити побудові моделі середовища на основіГ ІС платформи.

\section{СПИСОК ВИКОРИСТАНОЇ ЛІТЕРАТУРИ}

1. Про рішення Ради національної безпеки і оборони України від 20 травня 2016 року "Про Стратегічний оборонний бюлетень України"

2. Голобородько М. Ю. Теоретичні підходи щодо визначення місця інформаційної інфраструктури Міністерства оборони України у розумінні рамкових архітектурних методологій / М. Ю. Голобородько, В. А. Федорієнко, Ю. А. Кірпічніков [та ін.] // Збірник наукових праць Центру воєнно-стратегічних досліджень Національного університету оборони України імені Івана Черняховського. - 2016. - № 3(58). - С. 136-141. 
3. Кірпічніков Ю. А. Аналіз рамкових архітектур побудови інформаційних систем НАТО та визначення особливостей архітектури C4ISR [Електронний ресурс] / Ю. А. Кірпічніков, В. А. Федорієнко, О. В Головченко, О. В. Андрощук // Збірник наукових праць Центру воєнно-стратегічних досліджень Національного університету оборони України імені Івана Черняховського. - 2017. - № 1. - С. 78-84. 4. Шипулін В. Д. Основні принципи геоінформаційних систем: навчальний посібник (рос. мовою) / Володимир Дмитрович Шипулін. - Харків: ХНАМГ, 2010. - $337 \mathrm{c}$.

5. Szlachta B. Nato Architecture Framework. NATO Operational View. [Electronic Resource] / Bernard Szlachta // Noble Prog. - 2016. - Mode of access: http://training-coursematerial.com/index.php ?

6. Architecting the ArcGIS Platform: Best Practices [Електронний ресурс] // Esri. - 2017. - Режим доступу до ресурсу: https://www.esri.com/ / media/Files/Pdfs/products/arcgis-platform/architecting-thearcgis-platform.pdf

7. Підвищення інтелектуального рівня засобів обробки інформації в геоінформаційних системах військового призначення / О. А.Чорнокнижний, В. А. Савченко, А. Г. Салій, Г. М. Власенко. // Сучасні інформаційні технології у сфері безпеки та оборони. - 2010. - №1. C. 61-62.

8. Тарасов В. М. Проблемні питання створення географічної інформаційної системи в тактичній ланці управління військами (силами) / В. М. Тарасов, О. А. Чорнокнижний // Сучасні інформаційні технології у сфері безпеки та оборони. - 2012. - № 2. - С. 97-100.

9. The DoDAF Architecture Framework Version 2.02 [Electronic Resource] // Chief Information Officer U.S. Department of Defense. - 2011. - Mode of access: http://cionii.defense.gov/sites/ dodaf20/index.html.

10. C4ISR Architecture Framework Version 2.0 [Electronic Resource] // C4ISR Architecture Working Group U.S. Department of Defense. - 1997. - Mode of access: http://www.afcea.org/education/ courses/archfwk2.pdf.

11. GEOFidelis. SDSFIE Implementation Roles and Responsibilities Guide [Електронний ресурс] // The Spatial Data Standards for Facilities, Infrastructure, and Environment. - 2012. - Режим доступу до ресурсу: https://www.sdsfieonline.org/Documents/ GEOFidelis\%20SDSFIE\%20Implementation\%20Roles\%20 and\%20Responsibilities\%20Guide\%20v1.4.pdf.

12. National Spatial Data Infrastructure Strategic Framework [Електронний pecypc] // Federal Geographic Data Committee. - 2016. - Режим доступу до ресурсу: https://www.fgdc.gov/nsdi-plan/2017/nsdi-strategicframework-review-draft-v1.pdf.

13. GIS for Defense and Intelligence [Електронний ресурс] // Esri. - 2009. - Режим доступу до ресурсу: http://www.esri.com/library/brochures/pdfs/ gis-indefense.pdf.

Стаття надійшла до редакції 06.07.2017

Федориенко В. А.;

Головченко А. В.;

Васюхно С. И.

Центр военно-стратегических исследований Национального университета обороны Украины имени Ивана Черняховского, Киев

\section{Особенности современной концептуальной архитектуры ГИС платформы военного назначения}

Резюме. Статья раскрывает особенности ГИС архитектуры и ее роль для Вооруженных Сил Украины. Проведенный анализ предпосылок перехода на единую платформу ГИС и анализ подходов HATO по внедрению современных архитектур типа C4ISR. Определена необходимость использования архитектуры предприятия при внедрении ГИС платформы. Приведенные концептуальные особенности стратегии внедрения ГИС платформы и даны некоторые рекомендации..

Ключевые слова: рамочная архитектура, архитектура предприятия, ГИС платформа, C4ISR.

\section{Fedorienko;}

A. Golovchenko;

S. Vasukhno

Center for Military and Strategic Studies of the National Defence University of Ukraine named after Ivan Chernyhovsky, Kyiv

\section{Features of Contemporary Conceptual Architecture GIS Military Platform}

Resume. The article reveals the features of GIS architecture and its role for the Armed Forces of Ukraine. The analysis of modern GIS architectures and their adaptation to military appointment in NATO is considered. The taxonomy approaches are presented to achieve a systematic approach to the concept of NATO framework architecture.

The article reveals the features of GIS architecture and its role for the Armed Forces of Ukraine. The analysis of the preconditions for the transition to a single GIS platform and analysis of NATO approaches to the implementation of modern C4ISR-type architectures has been carried out. The necessity of using the architecture of enterprise in the implementation of GIS platform is determined. The conceptual features of the GIS platform implementation strategy are presented and some recommendations are given.

Keywords: framework architecture, enterprise architecture, C4ISR, evolution C4ISR. 